PAEDAGogia CHRISTIANA

$1 / 25$ (2010) - ISSN 1505-6872

Monika Sztamborska

Toruń

\title{
Niech stowa religii będa zawsze stowami pokoju Colloquia Torunensia XV, Toruń, 7 listopada 2009 roku
}

7 listopada 2009 roku w toruńskim Dworze Artusa odbyło się spotkanie z cyklu Colloquia Torunensia. Nawiązuje ono do Colloqium Charitativum rozmowy braterskiej pomiędzy katolikami, luteranami i kalwinistami, która została zwołana w 1645 roku z inicjatywy króla Władysława IV zaniepokojonego wzrostem nietolerancji religijnej. Celem spotkania było wzajemne poznanie założeń doktrynalnych oraz zrodzenie przekonania, że dzięki rozmowom można rozwiązać szereg spornych kwestii. Mimo iż obrady nie przyniosły konkretnych rozwiązań, przeszły do historii jako pierwsze pokojowe spotkanie międzywyznaniowe, dające początek ekumenizmowi. Od piętnastu lat w Toruniu odbywają się spotkania Colloquia Torunensia, na które zapraszani są przedstawiciele różnych religii. Tegoroczne spotkanie odbyło się pod hasłem, zaczerpniętym z wypowiedzi Jana Pawła II: „Niech słowa religii będą zawsze słowami pokoju". Jak co roku, komitet organizacyjny Colloquia Torunensia stanowili: Prezydent Miasta Torunia, Biskup Toruński, Rektor Uniwersytetu Mikołaj Kopernika w Toruniu oraz Prezes Towarzystwa Naukowego w Toruniu.

Jako pierwszy wystapił arcybiskup Henryk Muszyński z referatem pt.: „Pokój Mój daję wam” (J 14, 27) - Imiona pokoju. Na wstępie podkreślił, że termin „pokój” jest jednym z najczęściej używanych i zarazem wieloznacznych słów. Wyróżnił trzy zakresy znaczeniowe pokoju: pokój - jako nieobecność wojny pomiędzy narodami, grupami społecznymi lub poszczególnymi osobami; pokój jako owoc współżycia pomiędzy ludźmi, jako wyraz respektowania praw ludzkich i sprawiedliwości oraz pokój w wymiarze osobowym jako wewnętrzne pojednanie i zgoda z samym sobą, bliźnim, ze światem i z Bogiem. Podkreślił, że biblijne i teologiczne określenia pokoju 
- szalom i eirene nawiązują do wymienionych zakresów pokoju, jednak nie pokrywają się z żadnym z nich. Następnie przedstawił starotestamentalne korzenie pokoju Chrystusa. Biblijny termin szalom wyraża idee całości, nietykalności, ocalenia. W okresie przed niewolą pojęcie pokoju ograniczało się do ładu społeczno-religijnego ustawionego przez Boga, którego wykonawca był król. Po niewoli termin szalom otrzymał charakter religijny i mesjański oraz stał się wyrazem nadziei i oczekiwania idealnego króla przyszłości jako Księcia Pokoju. Ta prorocka tradycja została rozwinięta w Nowym Testamencie w osobie Jezusa Chrystusa. W rozumieniu chrześcijańskim pokój nie jest ani układem, ani teoria, ani systemem a jest równoznaczny ze zbawczym dziełem pojednania wysłużonego przez Chrystusa, czyli ostatecznie z samą Jego Osobą. Arcybiskup Muszyński po omówieniu pojęcia pokoju w pismach św. Pawła i Ewangeliach oraz w ujęciu św. Jana przedstawił wkład Kościoła w budowanie światowego pokoju. Prelegent przywołał opinię Józefa Ratzingera, że Kościół nie może narzucać własnej wizji pokoju. Jego zadaniem jest kształtowanie opinii i sumienia, wychowanie do postawy pokoju i pojednania, zabieranie głosu w sprawie pokoju, a przede wszystkim pełnienie służby miłości w odniesieniu do wszystkich potrzebujących i uciskanych. Arcybiskup Muszyński stwierdził również, że posługa Kościoła dla zachowania, obrony pokoju i do łagodzenia napięć, które mogą prowadzić do konfliktów, dokonuje się w podwójnym wymiarze: teoretycznym - poprzez nauczanie o pokoju oraz praktycznym - poprzez konkretne działanie zmierzające do łagodzenia napięć i konfliktów. Do działań związanych z nauczaniem Kościoła o pokoju należą przede wszystkim społeczne encykliki papieskie: Laborem exercens (1979), Sollicitudo rei socialis (1987), Centisimus annus (1991), Ut unum sint (1995). Podejmują one aktualne problemy, takie jak: różne formy niesprawiedliwości, przemocy, nędza materialna, gwałcenie podstawowych praw człowieka, fundamentalizm religijny oraz laicki. Kolejnym elementem nauczania Kościoła są papieskie Orędzia Pokojowe kierowane na początku każdego roku do całego świata. Bardzo ważną rolę odgrywają również pokojowe pielgrzymki Jana Pawła II oraz obecnego papieża Benedykta XVI. Paralelnie do teoretycznego nauczania o pokoju Kościół angażuje się w konkretne, wielopłaszczyznowe działanie stosownie do konkretnej sytuacji nacechowanej napięciem, walką czy wojną. Do zadań ludzi Kościoła należą: wychowanie do pokoju i kształtowanie sumień ludzkich, promowanie trwałych, obiektywnych norm i wartości, takich jak: godność człowieka, równość wszystkich ludzi wobec prawa oraz świadectwo i służba miłości, do której należą wszystkie działania zmierzające do łagodzenia konfliktów, budowania sprawiedliwości, przeciwdziałania egoizmowi i samowoli mocniejszych. Prelegent zakończył swoje wystąpienie morałem mówiącym, że pokój zaczyna się w naszych ser- 
cach; a sercem wszystkiego jest miłość i wypływające z niej przebaczenie i pojednanie.

Profesor Szewach Weiss zaprezentował referat pt.: Kiedy Żyd wypowiada słowo Shalom. Wypowiedź miała bardzo osobisty charakter i była świadectwem jego wojennych doświadczeń. Jako dziewięcioletni chłopiec wraz z rodzicami opuścił piwniczną kryjówkę. Rodzina przeżyła dzięki pomocy Julii Lasotowej, Marii Potężnej oraz rodziny Góralów. Profesor wspomniał, jak ważne było dla niego ukrywanie się w kryjówce pod kapliczką, na której stał krzyż. Powiedział, że wtedy po raz pierwszy jako żydowskie dziecko doświadczył wewnętrznego pokoju. Było to trudne doświadczenie dla niego, jako żydowskiego dziecka. Równie ważne było wyzwolenie przez armię radziecką i skierowane przez majora armii słów shalom oraz amchu do ,szkieletów" wychodzących z piwnic i kanałów. Wówczas cała rodzina otrzymała zupę i pierwszy po trzech latach kawałek świeżego chleba. Szewach Weiss jako przewodniczący Knesetu mógł wybrać kraj, w którym będzie pełnił służbę ambasadorską. Wybrał Polskę, Warszawę, mimo propozycji pracy w Moskwie i Berlinie. Pragnął powrócić do rodzinnych korzeni i nauczyć się języka polskiego. W domu rozmawiano w języku Jidysz, a podczas trzyletniego ukrywania się w piwnicy językiem było milczenie. Kolejnym ważnym wydarzeniem, którym referent się podzielił, było goszczenie przez niego, jako przewodniczącego Knesetu, Jana Pawła II. Wspomniał, że rozpierała go radość i duma, iż przyjmuje, jak sam określił, Sprawiedliwego Wśród Narodów Świata. Podkreślił mocną identyfikację z Papieżem-Polakiem. Pamięta jego przesłanie pokoju, z którym przyjechał do Izraela, oraz wielokrotnie powtarzane przez niego słowo shalom. W dalszej części wystapienia prelegent mówił o konflikcie izraelsko-palestyńskim oraz o potrzebie pokoju. Szewach Weiss ma świadomość, że proces zakończenia konfliktu potrwa jeszcze jakiś czas, ale równocześnie wierzy, że pokój jest potrzebny i jest możliwy. Swoją wypowiedź zakończył słowami: „I będzie shalom!”

Temat: Przesłanie pokoju w Koranie podją profesor Selim Chazbijewicz. Rozpoczynając wykład, powiedział, że Koran jest dla każdego muzułmanina Objawieniem i jest Słowem Boga, bez względu na interpretację tychże boskich wskazówek i nakazów. Podkreślił, że współczesny medialny obraz przedstawia islam jako religię terroryzmu, agresji i nietolerancji, której przedstawiciele nagminnie łamią prawa człowieka. Mówił, jak ważną wartość stanowi pokój w islamie. Muzułmanie pozdrawiają się słowami: „Niech pokój będzie z tobą". Stanowią one wstęp do dialogu, do otwarcia się na drugą osobę, bez względu jakiego jest wyznania. Referent zacytował fragment Koranu, świadczący o stawianiu na równi przez islam muzułmanów, chrześcijan i żydów. Następnie postawił pytanie, skąd bierze się fanatyczny, nietolerancyjny islam, skoro przesłaniem jego najważniejszej 
księgi jest tolerancja i pokój? Prelegent przedstawił budowę Koranu oraz wspomniał o Sunnie - Tradycji, która obok Koranu stanowi źródło prawa muzułmańskiego. Następnie w szczegółowy sposób zaprezentował polityczne podstawy współczesnych doktryn islamskich, które zaczęły powstawać w II połowie XIX wieku. Selim Chazbijewicz, analizując stosunek cywilizacji muzułmańskiej do świata chrześcijańskiego, przedstawił wiele świadectw podziwu, szacunku i zainteresowania. Zaznaczył, że społeczeństwa muzułmańskie, które zapoznały się głębiej z kulturą chrześcijańską, przejęły wiele z jej wartości, nie zatracając swojej islamskiej tożsamości. Wspomniał pielgrzymkę Jana Pawła II do Polski w 1999 roku, podczas której w Drohiczynie przedstawiciele polskich tatarskich muzułmanów przekazali Papieżowi w darze ryciny przedstawiające siedemnaście meczetów dawnej Rzeczpospolitej. Dar został opatrzny napisem: Polscy muzutmanie dziękuja Kościotowi katolickiemu, uosobionemu przez Waszq Świqtobliwość, za sześćset lat tolerancji wobec muzutmanów $i$ w państwie chrześcijańskim. Podsumowując swoje wystąpienie, Selim Chazbijewicz stwierdził, że współczesny obraz islamu stworzony przez media w Europie jest fałszywy i zdeformowany. Powiedział, że w dużej mierze należy wiązać go ze zdecydowaną mniejszością wśród wyznawców, która pod pozorem religii propaguje polityczną doktrynę religijnego faszyzmu i totalitaryzmu, stosując przemoc, terroryzm, rozpowszechniając fanatyzm i nietolerancję. Prelegent mocno podkreślił, iż mniejszość ta powinna być usilnie zwalcza również przez samych muzułmanów.

Ojciec Maciej Zięba w referacie pt.: Jan Pawet II $w$ stużbie pokoju przedstawił inicjatywy Jana Pawła II na polu budowania pokoju. Papież był przekonany, że pojęcia pokoju nie można zawężać wyłącznie do sytuacji braku konfliktu. W definiowaniu tego pojęcia nawiązywał do klasycznej definicji pokoju, pochodzącej od św. Augustyna: Tranquillitas Ordinis - pokój płynący z ładu, jedności, uporządkowania. Dlatego wszystkie działania Następcy Piotra zmierzały do budowania jedności. Bardzo widoczne było to w kontaktach z przedstawicielami różnych religii. Egzemplifikację stanowi wspólna modlitwa w Asyżu oraz otwarcie drzwi Bazyliki św. Pawła za Murami w roku jubileuszowym wraz z metropolitą prawosławnym Atanazym oraz arcybiskupem Canterbury Careyem. Prelegent wspominał również o 14 wizytach w autokefalicznych Kościołach prawosławnych. Podkreślił, że Jan Paweł II był pierwszym papieżem (od czasów św. Piotra) w synagodze w 1986 roku oraz pierwszym Papieżem, który odwiedził meczet - meczet Umajjadów w Damaszku. Po wizycie w Yad Vashem jeden z rabinów powiedział, że „Papież przerzuca mosty nad rzekami krwi”. Nawiązując do tej metafory Ojciec Maciej Zięba wspomniał o papieskiej misji, wynikającej z tytułu Pontifex Maximus - Najwyższy Budowniczy Mostów. Jan Paweł II 
zadanie budowania mostów realizował w bardzo precyzyjny sposób. W Jerozolimie naszkicował program budowania jedności. Papież wskazał wówczas na trzy wymiary: „Po pierwsze, naszym celem jest, abyśmy, trzymając się swoich przekonań, z szacunkiem słuchali jeden drugiego; po drugie, byśmy starali się rozpoznać to, co jest dobre i święte w innych doktrynach; po trzecie, byśmy współpracowali w popieraniu wszystkiego, co sprzyja wzajemnemu zrozumieniu i pokojowi”. Prelegent wspomniał o działaniu Jana Pawła II zmierzającym do wskazania różnicy między wiarą oraz ideologią. W tym celu rozpoczął proces samooczyszczania świadomości Kościoła. Liczne papieskie sympozja na temat inkwizycji, korzeni antyjudaizmu, problemu Jana Husa czy Galileusza stanowiły rachunek sumienia Kościoła, miały również na celu ułatwić relację z innymi religiami. Prelegent powiedział, że kolejnym działaniem Jana Pawła II w dążeniu do budowania jedności i tym samym pokoju były liczne kanonizacje i beatyfikacje osób zaangażowanych w dzieła miłosierdzia, które same często były ubogie i po ludzku mało znaczące. Papież służąc pokojowi podnosił kwestie godności mężczyzny i kobiety. Zwracał uwagę, że fundamentem pokoju jest respektowanie praw człowieka, a w szczególności prawa do życia i wolności religijnej. Maciej Zięba, podsumowując wystapienie, podkreślił dużą aktywność Stolicy Apostolskiej, osobistych wysłanników Jana Pawła II i samego Papieża, który budował pojednanie, inicjował przekraczanie podziałów, budował pokój oraz swoim głosem wspierał ludzi prześladowanych.

XV Colloquia Torunensia dotyczyły zaangażowania różnych religii w budowanie pokoju. Arcybiskup Henryk Muszyński zaprezentował wieloznaczność tego terminu. Wyjaśniał konteksty historyczno-kultorowe kreowania pojęcia pokoju. Szczegółowo omówił jego znaczenie na kartach Starego i Nowego Testamentu oraz w pismach św. Pawła. Przedstawił również wkład Kościoła w budowanie światowego pokoju. Profesor Szewach Weiss podzielił się osobistymi doświadczeniami wojennymi. Po tak tragicznych wydarzeniach, w których uczestniczył jako dziecko na polskiej ziemi oraz nadal doświadcza w ojczystej ziemi, Jego wiara w nastanie pokoju szczególnie napawa optymizmem. Myślę, że wszystkim słuchaczom zapadły w pamięć Jego słowa kończące wystąpienie: „I będzie szalom!!!” Kończąc swoją wypowiedź Szewach Weiss zaprosił na scenę prof. Selima Chazbijewicza mówiąc, że to nie jest ich pierwsze spotkanie. Znaczył, że nie tylko tu jest możliwe wzajemne ściskanie się żyda i muzułmanina, ale jest to możliwe wszędzie i stanowi to wezwanie nas wszystkich do życia w pokoju i wzajemnym poszanowaniu. Selim Chazbijewicz zaprezentował przesłanie pokoju w Koranie. Kontestował przeciwko przedstawianiu islamu w mediach jako religii terroru. Winą za to obarczył muzułmańską mniejszość religijną, która sprzeciwiła się ideom Koranu, czyniąc z religii polityczną ideologię. 
W swojej wypowiedzi wielokrotnie cytował Koran wskazując, że islam jest religią pokoju wobec innych wyznań. Ostatnim referentem był dominikanin Maciej Zięba, który przedstawił Jana Pawła II w służbie pokoju. Wspomniał o licznych papieskich pielgrzymkach, podczas których zawsze występował w obronie godności człowieka i poszanowania jego praw. Ks. prof. Jerzy Bagrowicz, podsumowując XV Colloquia Torunensia, wyraził wdzięczność prelegentom za przybycie i za wkład w budowanie pokoju. Tegorocznym referentom, przedstawicielom islamu, judaizmu oraz katolicyzmu przyświecały słowa Jana Pawła II: „Niech słowa religii będą zawsze słowami pokoju”. 